\title{
A New Alkaloid from Two Coccinellid Beetles Harmonia axyridis and Aiolocaria hexaspilota
}

\author{
Naseer Alam, In Soo Choi, Kyung-Sik Song, ${ }^{\dagger}$ Jongki Hong, ${ }^{\ddagger}$ Chong O. Lee, $\$$ and Jee H. Jung \\ College of Phamacy, Pusan National Chiversin, Pusan 609-735, Korea \\ Department of Biochemistry, Kiungpook National Cniversity. Taegu 702-701. Korea \\ ${ }^{\ddagger}$ Korea Basic Science Institute, Seoul 136-701, Korea \\ $\$$ Pharmaceutical Screening Center, Korea Research Institute of Chemical Technologu. Daejeon 305-3+3. Korea \\ Received.August +. 2001
}

Keywords: Coccinellid beetles, Hamonia axyridis, fiolocaria hexaspilota, Cytotoxicity. Alzheimers disease.

Coccinellid beetles are known to secrete droplets of blood from the joints when they are molested. ${ }^{1}$ A number of alkaloids are present in this reflex bleeding which is considered as a mode of their chenical defense. These alkaloids are also responsible for their aposematic coloration. About fifty alkaloids like azaphenalenes. azabicyclononanes, harmonine. pyrrolidines. piperidines. aromatic anines. azamacrolides. and some dimmeric alkaloids have so far been isolated from about thirty five species of the Coccinellidae..$^{-4}$ The deterrent and toxic properties of these defensive alkaloids prompted

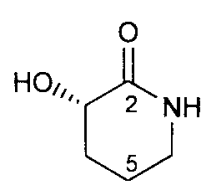

1

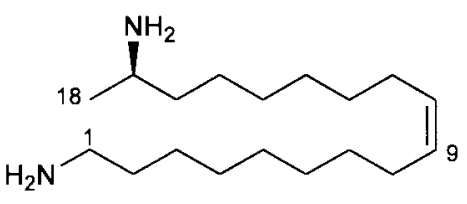

2 us to investigate Harmonia anyidis and Aiolocaria hexaspilota for their alkaloidal constituents. We here report the isolation of a new natural product 3-hydroxypiperidin-2-one (1) and harmonine (2) from these species of Coccinellidae.

Compound 1 was isolated as a light yellow solid. The [M $+\mathrm{H}]^{+}$peak was observed at $m z 116,0-712$ in the HRFABMS which corresponded to the molecular formula $\mathrm{C}_{3} \mathrm{H}_{9} \mathrm{NO}_{3}$. The formula showed two degrees of unsaturation. A broad band at $3398 \mathrm{~cm}^{-1}$ in the IR spectrum suggested the presence of $\mathrm{OH}$ and $\mathrm{NH}$ groups. A strong band at $1619 \mathrm{~cm}^{-1}$ indicated an intra-molecular hydrogen bonded carbonyl group.

The ${ }^{l} \mathrm{H}$ NMR of 1 displayed a proton signal at $\delta 3.94$ that was correlated to a carbon signal at $\delta 62.5$. This signal showed correlations with the methylene protons at $\delta 2.28$ and 2.09. The methylene proton signals at $\delta 3.36$ and 3.20 showed correlation with a carbon signal at $\delta 46.5$ indicating that they are vicinal to a nitrogen function. These proton

"To whom correspondence should be addressed. Tel.: +82-51510-2803: Fax: +82-51-510-2803; E-mail: jhiung ầpusan ac.kr signals showed strong correlation with the methylene proton signal at $\delta 1.96$ that showed further correlations with the methylene proton signals at $\delta 2.28$ and 2.09. Thus the entire proton signals in the COSY spectrum comprised a single spin system. The ${ }^{13} \mathrm{C}$ NMR spectrum featured a carbonyl carbon at $\delta 174.5(\mathrm{C}-2)$, an oxygenated carbon at $\delta 62.5$ (C3). and a carbon attached to nitrogen at $\delta 46.5$ (C-6). The signals at $\delta 31.0$ and 24.5 were assigned to $\mathrm{C}-4$ and $\mathrm{C}-5$. respectively, and ${ }^{1} \mathrm{H}^{13} \mathrm{C}$ connectivities were confirmed by an HMQC experiment. The COSY and HMBC correlations were also in accordance with the proposed structure (Figure 1). Thus the gross structure was determined as 3-hydroxypiperidin-2-one. The compound showed an optical rotation of $-53^{\circ}$ which was the same in sign to that of the earlier sy'nthesized $(S)$-3-hydroxypiperidin-2-one $\left([\alpha]_{[}^{3 !}-6^{\circ}\right)^{56}$ but the degree of rotation was different. The isolated compound was quite pure and the structure was well established by $2 \mathrm{D}$ NMR techniques so we deduce that $\mathbf{1}$ also has $(3 S)$-stereochemistry. This compound has previously been șinthesized ${ }^{6}$ but to the best of our knowledge it is the first report of its occurrence as a natural product. The reported $\mathrm{mp}$ of the synthetic compound varied from 133 to $171{ }^{\circ} \mathrm{C}$. depending on its optical purity ${ }^{5.7-9}$ Compound 1 has melted at 122-124 ${ }^{\circ} \mathrm{C}$ and decomposed at $190-192^{\circ} \mathrm{C}$.

Compound 2 was a brownish oil. Its ${ }^{1} \mathrm{H}$ NMR featured the presence of a terminal methyl $(\delta 1.04 .3 \mathrm{H} . \mathrm{d} . J=7.0 \mathrm{~Hz}$. $\mathrm{H}-18)$, a methine $(\delta 2.82-2.90,1 \mathrm{H}, \mathrm{m})$ and methylene protons $(\delta 2.67 .2 \mathrm{H}, \mathrm{t} . J=7.0 \mathrm{~Hz})$ vicinal to a nitrogen atom. and a mono-unsaturated alkyl chain. The assignments were confirmed by COSY correlations and were supported by ${ }^{13} \mathrm{C}$

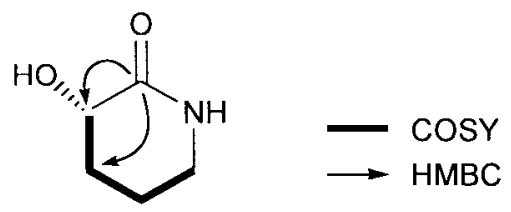

Figure 1. Key COSY and HMBC correlations for compound 1. 
Table 1. In Iñtro Cytotoxicities ( $\mathrm{ED}_{s_{0}} \mu \mathrm{g} / \mathrm{mL}$ ) of 1 and 2 against Hunnan Solid Tunnor Cells ${ }^{\text {at }}$

\begin{tabular}{lccccc}
\hline compound & A549 & SK-OV-3 & SK-MEL-2 & XF498 & HCT15 \\
\hline 1 & $>30$ & $>30$ & $>30$ & $>30$ & $>30$ \\
cisplatin & 0.72 & 1.23 & 2.26 & 1.03 & 1.10 \\
doxonubicin & 0.02 & 0.11 & 0.02 & 0.08 & 0.04 \\
\hline 2 & 3.04 & 2.86 & 2.87 & 1.03 & 1.10 \\
cisplatin & 0.40 & 0.77 & 0.98 & 0.48 & 0.41 \\
doxorubicin & 0.01 & 0.02 & 0.02 & 0.03 & 0.02 \\
\hline
\end{tabular}

"A 549: human lung cancer: SK-OV-3: human ovarian cancer; SK-MEL2: human skin cancer: XF498: human CNS cancer, HCT15: human colon cancer. The compounds were assaved in two separate batches.

Table 2. Enzyme Indhibitory Activity of $2^{\prime \prime}$

\begin{tabular}{cccc}
\hline $\begin{array}{c}\text { Concentra- } \\
\text { tion }\end{array}$ & $\begin{array}{c}\text { Acetycholine- } \\
\text { sterase }\end{array}$ & $\begin{array}{c}\text { Prolylendo- } \\
\text { peptidase }\end{array}$ & $\begin{array}{c}\text { Neuramini- } \\
\text { dase }\end{array}$ \\
\hline $5 \mu \mathrm{g} / \mathrm{mL}$ & 12 & 53 & 5 \\
$40 \mu \mathrm{g} / \mathrm{mL}$ & 47 & 64 & 12 \\
\hline
\end{tabular}

"Expressed as "o inhibition.

NMR spectrum. The LRFABMS showed an $[\mathrm{M}+\mathrm{H}]^{+}$ion at $m z 283$ which gave a molecular formula $\mathrm{C}_{18} \mathrm{H}_{38} \mathrm{~N}_{2}$ in combination with the NMR data. The location of the double bond was determined based on the significant allylic cleavages at $m: 168$ and 114 in the FAB-CID MS/MS. These findings suggested the gross structure of compound 2 as harmonine. previously isolated from Harmonia leis conformis and Hippodamic convergens. ${ }^{16}$ The geometry of the double bond was determined as cis on the basis of the chemical shift value of the allylic carbons (see Experimental) while the absolute stereochemistry was presumed to be the same as that of harmonine. ${ }^{11}$

Compounds 1 and 2 were evaluated for their cytotoxicity against five human solid tumor cell lines, and $\mathbf{2}$ was found to posses significant cytotoxicity against these cell lines (Table 1). Compound 2 was also evaluated for its inhibitory activity on several enzymes that are considered as therapeutic targets of Alzheimer's disease. It showed a week inhibitory activity against acetylcholinestrase $(\mathrm{AChE})$, prolylendopeptidase (PEP), and neuraminidase (Table 2).

\section{Experimental Section}

General Experimental Procedures. Melting point was measured on an Electrothermal digital melting point apparatus and was uncorrected. Optical rotations were measured on a JASCO DIP-370 digital polarimeter. IR spectra were obtained using a JASCO FT/RR-410 spectrometer. ${ }^{1} \mathrm{H}$ and ${ }^{13} \mathrm{C}$ NMR spectra were recorded on a Varian Unity Plus 300 . and Varian INOVA 500 spectrometers. Chemical shifts were reported in reference to the respective residual solvent peaks $\left(\delta_{\mathrm{H}} 3.3\right.$ and $\delta \mathrm{c} 49.0$ for $\mathrm{CD}_{3} \mathrm{OD}$ ). COSY spectra were recorded on a Varian INOVA 500 spectrometer and Bruker DMX 600 spectrometer for compound 1 and 2 . respectively. HRFABMS data were obtained using a JEOL JMS-HX110/
110A. HPLC was performed on a Gilson 370 pump with a YMC amino $12 \mathrm{~S} 05(250 \times 10 \mathrm{~mm}$ i.d.. S-5 $\mu \mathrm{m} .120 \AA)$ and YMC ODS-H80 $(250 \times 10 \mathrm{~mm}$ i.d., S-4 $\mu \mathrm{m} .80 \AA)$ column using a Shodex RI-7l detector.

Animal Material. About 1000 adult ladybird beetles were collected and were kept at $-20^{\circ} \mathrm{C}$ until extraction.

Isolation of Compounds. The frozen beetles were extracted with $\mathrm{MeOH}$ at room temp. and the combined extract was filtered and vacuum dried on a rotary evaporator to give a thick paste $(9 \mathrm{~g})$. Reversed-phase flash chromatographic separation of this extract with $20 \rightarrow 0 \% \mathrm{H}_{2} \mathrm{O} / \mathrm{MeOH}$ and fully with acetone gave 5 fractions. Fraction 2 showed high cytotoxicity in the brine shrimp assay ${ }^{13}$ and was further separated into 16 fractions on reversed-phase MPLC (ODS, $\mathrm{MeOH}: \mathrm{H}_{2} \mathrm{O}, 7: 3$ ). Fraction 2.2 was chromatographed on a reversed-phase $\mathrm{HPLC}$ (ODS. $\mathrm{MeOH}: \mathrm{H}_{2} \mathrm{O}, 3: 7$ ) into 8 fractions and repeated $\mathrm{HPLC}$ purification (amino. $\mathrm{CH}_{3} \mathrm{CN}$ : $\left.\mathrm{H}_{2} \mathrm{O}, 7: 3\right)$ of fraction $2-2 \cdot 1$ yielded compound $1(94 \mathrm{mg}$ ). Fractions 2-4-2-16 were combined into a single fraction (fraction 2-4) on the basis of TLC and brine shrimp assay and was further separated on chromatotron ( $\mathrm{Si}$ gel. $2 \mathrm{~mm}$ ) eluting with a gradient of $\mathrm{CH}_{2} \mathrm{Cl}_{2}: \mathrm{MeOH}: \mathrm{NH}_{3}(9: 1: 0.1$ $\rightarrow 1: 1: 0.1)$ to give 7 fractions. Fraction 2-4-4 yielded compound $2(13.5 \mathrm{mg})$ on further purification by HPLC (amino, $\mathrm{CH}_{3} \mathrm{CN}: \mathrm{H}_{2} \mathrm{O}, \mathrm{l}: \mathrm{l}$ ).

Compound 1: Yellowish brown solid: mp 122.124 ${ }^{\circ} \mathrm{C}$ (decomp. 190-192 ${ }^{\circ} \mathrm{C}$, lit. $171.5^{\circ} \mathrm{C}^{5}$. 143-145 ${ }^{\circ} \mathrm{C}^{7}$. 135-137 $\left.{ }^{\circ} \mathrm{C}^{8} .133-135^{\circ} \mathrm{C}^{9}\right):[\alpha]_{\mathrm{c}^{\circ}}^{18}-53^{\circ}(c 0.8, \mathrm{MeOH}) ; \mathrm{IR} v_{\max }($ film) $3398.1619,1405 \mathrm{~cm}^{-1},{ }_{1}^{1} \mathrm{H} \mathrm{NMR}\left(500 \mathrm{MHz}\right.$. CD $\left.{ }_{3} \mathrm{OD}\right) 83.94$ (lH. dd. $J=7.9 .6 .4 \mathrm{~Hz} . \mathrm{H}-3), 3.36(\mathrm{lH} . \mathrm{dt}, J=11.6 .5 .8 \mathrm{~Hz}$, $\mathrm{H}-6) .3 .20(1 \mathrm{H}, \mathrm{dt} . J=11.6 .7 .3 \mathrm{~Hz} . \mathrm{H}-6), 2.28(\mathrm{lH} . \mathrm{ddd}, J=$ 12.8. $7.9 .7 .9 \mathrm{~Hz}, \mathrm{H}-4), 2.09$ (lH. ddd. $J=12.8,6.4 .6 .4 \mathrm{~Hz}$, $\mathrm{H}-4)$. 1.94-1.99 (2H. m, H-5): ${ }^{13} \mathrm{C} \mathrm{NMR}\left(125 \mathrm{MHz}, \mathrm{CD}_{3} \mathrm{OD}\right)$ $\delta 174.5$ (C-2), 62.5 (C-3), 46.5 (C-6). $31.0(\mathrm{C}-4), 24.5$ (C-5). HRFABMS $m_{2} 116.0713\left[\mathrm{M}+\mathrm{H}^{+}\right.$(calcd for $\mathrm{C}_{5} \mathrm{H}_{1 \mathrm{~N}} \mathrm{NO}_{2}$, $116.0712, \Delta+0.1 \mathrm{mmu})$

Compound 2: Brownish oil; ${ }^{1} \mathrm{H}$ NMR $\left(300 \mathrm{MHz}, \mathrm{CDCl}_{3}\right)$ $\delta 5.30-5.40$ (2H. m. H-9, H-10). 2.82-2.90 (1H. m. H-17), $2.67(2 \mathrm{H} . \mathrm{t}, J=7.0 \mathrm{~Hz} . \mathrm{H}-1) .1 .95 \cdot 2.05(4 \mathrm{H}, \mathrm{m} . \mathrm{H}-8, \mathrm{H}-1 \mathrm{l})$. $1.11-1.40(22 \mathrm{H}$. br s. alkyl chain). $1.04(3 \mathrm{H} . \mathrm{d} . J=7.0 \mathrm{~Hz}$, $\mathrm{H}-18) ;{ }^{13} \mathrm{C}$ NMR $\left(75 \mathrm{MHz}, \mathrm{CDCl}_{3}\right) \delta 130(\mathrm{C}-9, \mathrm{C}-10) .46 .5$ (C-17). 41.5 (C-1), 28-30 (alkyl chain), 27.0 (C-8. C-11), 23.0 (C-18); FAB-CID MS/MS $m z 283$ [M+ H] ${ }^{-}(100), 268$ $\left[\mathrm{M}-\mathrm{CH}_{3}\right]^{+}(3) .239(0.1) .224(0.1) .210(0.1) .196(0.1) .182$ $(0.2) .169(0.2), 155(0.1), 140(0.1), 114(0.2) .44(1.2)$.

\section{References}

1. Happ, G. M.: Eisner, T. Science 1961, 134. 329-331.

2. Angela. G. K.: Meinwald. J. Chem. Rev. $1996,96,1105-1122$.

3. Lebrun. B.; Braekman, J.C.: Daloze, D.; Kalushkiov, P.: Pasteels, J. M. Tetrahedron Lett. 1999. 40.8115-8116.

4. Daloze. D.: Braekman1. J.-C.: Pasteels. J. M. Chenoecologv 1995. 5.6. 173-183.

5. Hunter. A.; Woodward. H. E. Biochem. J. 1941, 35, 1298-1306.

6. Gibbs. G.: Hateley, M. J.; McLaren, L.: Welham, M:; Willis, C. L. Tetrahedron Lett. 1999. 10. 1069-1072.

7. Hua. D. H.: Zhang. F.: Chent. T.: Robinson. P. D. J. Org. Chen. 
$1994,59,5084-5087$.

8. Hjeds. H.: Honore. T. Acta Chem. Scand 1978. B32. 187-192.

9. Elming. N. Acta Chem. Scand 1957. 11.914.

10. Braconnier. M. F.: Braekman. J.-C.: Daloze. D.: Pasteels. J. M. Experiemia 1985, $+1.519-520$.
11. Braconnier. M. F.; Braekman, J.-C:; Daloze. D. Bull. Soc. Chim. Belg. 1985. 94. 605-613.

12. Meyer. B. N.: Ferrigni. N. R.: Putt1am. J. E.: Jacobsent. L. B.: Nichols. D. E.: McLaughlin. J. L. Plamta Medica 1982. +5. 31-34. 